down to Virgil, Pliny and Vitruvius for the Roman period.

In Europe a number of manuscripts such as the Mappa Clavicula and the Compositiones ad tingenda, written in the ninth century, give some details of soldering and brazing, but the most workmanlike account is that of the German monk who called himself Theophilus. His De Diversis Artibus, compiled in about 1125 , includes a full description of gold soldering and the preparation of a flux from beechwood ashes, soap, hog's lard and a mixture of copper salts.

In prehistoric times the choice of a suitable brazing alloy must have been by trial and error, but by about 500 B.C. it was realised that an alloy of one part of copper to two parts of gold was effective. From then on recipes for gold solders appear fairly frequently, ranging from around this composition to about one third copper.

By 1568 the great Italian goldsmith and sculptor Benvenuto Cellini was using gold-copper-silver alloys as brazing materials, and understood that, in the making of a succession of joints, "you must introduce a fresh alloy of silver and copper so as to prevent the solder of the time before from running".

Little further development seems to have occurred over the next 250 years, but by the very beginning of the nineteenth century the invention of the oxyhydrogen blowpipe by Robert Hare, Professor of Chemistry in the University of Pennsylvania-and the later discovery of acetylene by Friederich Wöhler-had made available reliable means of achieving high temperatures for gold brazing on a production scale, while the later development of physical metallurgy began to provide a number of gold alloys containing nickel and other elements suitable for various types of soldering and brazing.

Altogether this is a fascinating little book, in which one can trace an unbroken tradition of working methods from the ancient Near East through medieval Europe until quite recent times.

L. B. H.

\title{
Gold Working Practice at Pompeii
}

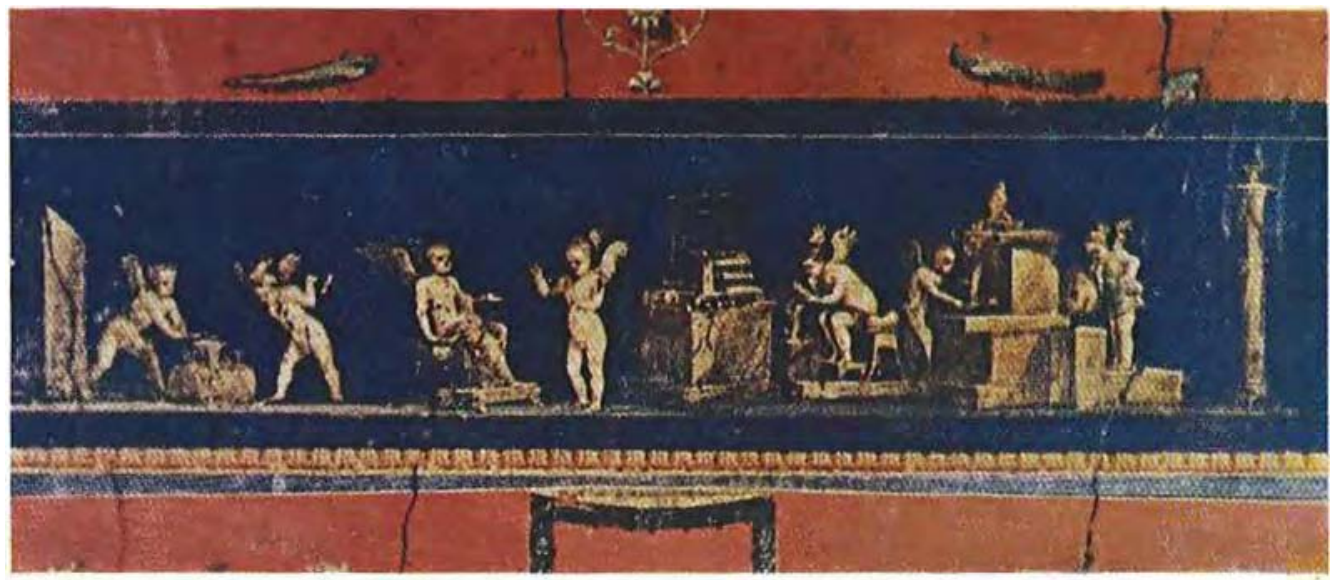

Among the most remarkable features of Pompeii, overwhelmed by an eruption of Vesuvius in A.D. 79 and now extensively excavated and preserved, is the series of charming and colourful wall paintings that decorate the House of the Vettii, an early building restored by two wealthy merchants, the brothers Aulus Vettius Restituto and Aulus Vettius Conviva, towards the end of the city's life. These show various scenes from the arts and occupations of the time, including the making and selling of oils and perfumes, the gathering of grapes and the making of wine, and the melting and working of gold. In all these scenes the artist made use of little Cupids to take the place of workmen. In the gold working scene the melting furnace at the right bears the head of Hephaestos, the patron of metal workers; on the left Cupids are forging an ingot with hammer and anvil. To the left of the melting furnace a blowpipe is being used, most probably for a soldering operation, and to the left again a customer is being served by another Cupid holding a balance to weigh the gold being purchased. 